\title{
OPEN Invasive Lactuca serriola seeds contain endophytic bacteria that contribute to drought tolerance
}

\author{
Seorin Jeong, Tae-Min Kim, Byungwook Choi, Yousuk Kim \& Eunsuk Kim ${ }^{凶}$
}

The mutualistic relationship between alien plant species and microorganisms is proposed to facilitate or hinder invasive success, depending on whether plants can form novel associations with microorganisms in the introduced habitats. However, this hypothesis has not considered seed endophytes that would move together with plant propagules. Little information is available on the seed endophytic bacteria of invasive species and their effects on plant performance. We isolated the seed endophytic bacteria of a xerophytic invasive plant, Lactuca serriola, and examined their plant growth-promoting traits. In addition, we assessed whether these seed endophytes contributed to plant drought tolerance. Forty-two bacterial species were isolated from seeds, and all of them exhibited at least one plant growth-promoting trait. Kosakonia cowanii occurred in all four tested plant populations and produced a high concentration of exopolysaccharides in media with a highly negative water potential. Notably, applying $K$. cowanii GG1 to Arabidopsis thaliana stimulated plant growth under drought conditions. It also reduced soil water loss under drought conditions, suggesting bacterial production of exopolysaccharides might contribute to the maintenance of soil water content. These results imply that invasive plants can disperse along with beneficial bacterial symbionts, which potentially improve plant fitness and help to establish alien plant species.

Endophytic bacteria are non-pathogenic microbes that occur within plant tissues, including the stems, seeds, leaves, and fruits ${ }^{1,2}$. Endophytic bacteria have received considerable attention because they stimulate plant growth by producing plant growth-promoting (PGP) molecules or increasing plant resistance to biotic and abiotic environmental stresses ${ }^{3-6}$. Endophytes occurring inside seeds are of particular interest because they can be vertically transmitted from parents to offspring, effectively behaving as additional genes in their host ${ }^{7}$. Although seed endophytic bacteria from crop plant species and their application in agricultural activities have been widely investigated ${ }^{8,9}$, relatively little information is available on the ecological significance of these bacteria ${ }^{7,10}$.

Diverse abiotic and biotic factors determine the invasiveness of non-native plant species ${ }^{11,12}$. An important attribute of invasive success is the development of mutualistic relationships between invasive plants and microorganisms ${ }^{13,14}$. As invasive plants tend to disperse across a broad geographic range and colonize novel habitats, previous studies have stressed that the contribution of mutualism to invasive success would be highly dependent on the presence of novel mutualistic bacteria in the introduced habitats ${ }^{13,15,16}$. However, it should be noted that seed endophytic bacteria can disperse along with the host plants ${ }^{17}$. It is possible that seed endophytic bacteria improve the fitness of invasive plants, similar to the bacteria occurring in the rhizosphere or leaves ${ }^{18-20}$. Invasive plants might benefit from seed endophytic bacteria instead of bacteria in the introduced habitats for their successful establishment.

Here, we isolated and characterized the seed endophytic bacteria of an invasive plant species, Lactuca serriola (Asteraceae). L. serriola is an annual or biennial herbaceous plant species that originated in Europe. Since it was first reported as an alien species in 1978, its range has expanded rapidly across South Korea ${ }^{21,22}$. The high drought tolerance of $L$. serriola has been suggested as a critical trait facilitating its successful invasion of open habitats, including roadsides, vacant lots, and ruins ${ }^{21,23,24}$.

We examined if seed endophytic bacteria produced PGP molecules, which are believed to promote plant growth ${ }^{25}$. In addition, we tested if these bacteria contributed to the drought tolerance of host plants. It has previously been demonstrated that bacterial production of exopolysaccharides (EPS) plays a critical role in 


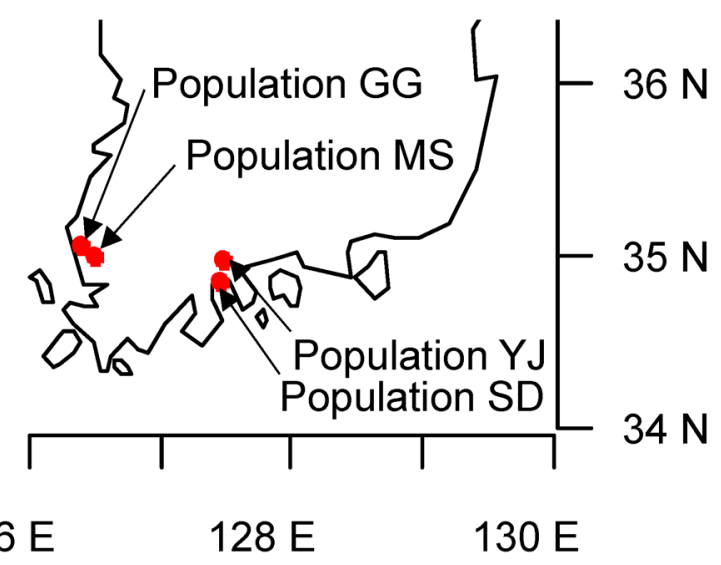

Figure 1. Sampling sites of Lactuca serriola. Seeds were collected from two distant geographical regions (Muangun and Suncheon-si) with two sampling sites each. The map was generated using maps package in $\mathrm{R}$ (Version 4.0.1, https://www.cran.r-project.org/web/packages/maps/maps.pdf).

increasing the drought tolerance of plants in addition to their effects on microbial physiology ${ }^{26}$. In particular, EPS-producing rhizobacteria efficiently colonize plant roots and aggregate rhizosphere soil by increasing the inter-particle cohesion forces among the soil particles, thereby increasing soil porosity and retention time of soil moisture ${ }^{27-29}$. Consequently, they can increase the adhering soil-to-root tissue ratio and alleviate water stress. We evaluated the EPS produced by the isolated seed endophytes and assessed if seed endophyte infection increased the drought tolerance of a model plant species, Arabidopsis thaliana.

\section{Results}

Identification of seed endophytic bacteria and their PGP traits. We collected wild L. serriola seeds from four natural populations in the vicinity of the Gwangju Institute of Sciences and Technology, Gwangju, South Korea (Fig. 1, Supplementary Table S1). Seeds from 4-12 plants from each population were composited, and 80 seeds from each composite sample were used to isolate endophytic bacteria.

A total of 129 bacterial strains were isolated, and their 16S rDNA sequences were compared with previously reported sequences of bacterial type strains in the EZBioCloud database (Chunlab, Seoul, South Korea). The $16 \mathrm{~S}$ rDNA sequences of all isolates exhibited more than $99 \%$ similarity with the type strains. A total of 18 genera were identified (Fig. 2, Table 1): Acidovorax, Bacillus, Cellulosimicrobium, Chryseobacterium, Cronobacter, Curtobacterium, Enterobacter, Enterococcus, Erwinia, Exiguobacterium, Kosakonia, Paenibacillus, Pantoea, Pseudomonas, Rhizobium, Saccharibacillus, Stenotrophomonas, and Xanthomonas. K. cowanii was detected in all four populations, and Cr. dublinensis was detected in three populations (Fig. 3). Across all plant populations, most isolates belonged to Gammaproteobacteria (Fig. 2). Firmicutes constituted 13-25\% of the isolates, whereas no Firmicutes specimens could be detected in the YJ population. Alpha- and Betaproteobacteria, Actinobacteria, and Bacteroidetes were detected in either MS or GG populations, but not in YJ and SD populations.

PGP traits were examined for 42 representative isolates (Table 1; Supplementary Fig. S1). All tested isolates produced ACC deaminase, and $95.2 \%$ of the isolates could grow without a nitrogen source. In addition, $85.7 \%$ and $69 \%$ of the isolates could solubilize insoluble phosphate and produce siderophores, respectively. Less than half of the isolates produced IAA. IAA production was not observed for K. cowanii isolated from the GG site, whereas it was detected for those from other sites. Thus, even though isolates were assigned to the same species based on their 16S rDNA sequence similarity, their PGP activities likely depended on their source population. These 42 isolates have been deposited in the Korean Collection for Type Cultures (KCTC) (Table 1).

Bacterial growth under drought conditions and EPS production. All 42 representative isolates produced capsular materials outside their cells (Supplementary Fig. S1). When the isolates were grown in media with a water potential of $-0.73 \mathrm{MPa}, \mathrm{Pa}$. ananatis SD16 presented the highest OD value (1.65), whereas $\mathrm{Pa}$. nicotianae MS14 presented the lowest OD value (0.27) (Supplementary Fig. S1). For EPS quantification, K. cowanii and the two isolates with the highest OD values were selected from each source population.

The bacterial isolates grown in media with a water potential of $-0.73 \mathrm{MPa}$ tended to produce more EPS than those grown under non-stress condition $(\mathrm{F}=8.09, P<0.01)$. Notably, isolates responded differently to the stress condition, as indicated by the significant isolate $\times$ condition interaction $(\mathrm{F}=47.62, P<0.001)$ (Fig. 4). EPS production increased under stress condition in $K$. cowanii $\mathrm{YJ} 4(\mathrm{t}=6.04$, adjusted $P<0.001)$, K. cowanii SD1 $(\mathrm{t}=5.33$, adjusted $P<0.001), K$. cowanii MS1 $(\mathrm{t}=17.12$, adjusted $P<0.001), K$. cowanii GG1 $(\mathrm{t}=16.95$, adjusted $P<0.001)$, and $P a$. ananatis GG19 $(\mathrm{t}=13.91$, adjusted $P<0.001)$. In contrast, Erwinia tasmaniensis $\mathrm{YJ} 6$ exhibited lower EPS production under stress condition $(\mathrm{t}=9.00$, adjusted $P<0.001)$. K. cowanii MS1 exhibited the highest EPS production $(719.00 \mu \mathrm{g} / \mathrm{mL})$, whereas Pa. hunanensis GG17 presented the lowest EPS production $(76.67 \mu \mathrm{g} /$ $\mathrm{mL}$ ) under stress condition. 


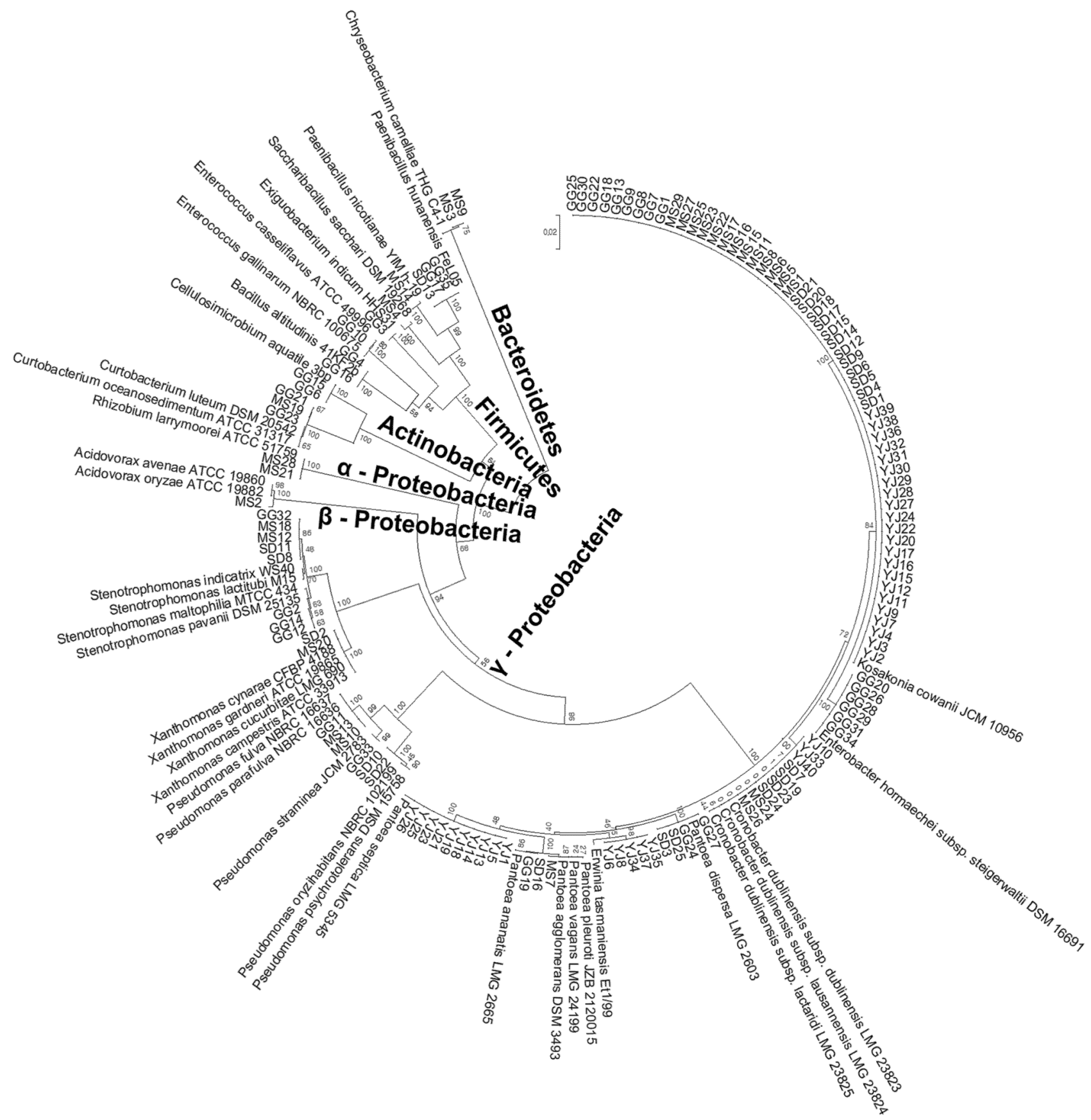

Figure 2. A phylogenetic tree constructed based on the $16 \mathrm{~S}$ rDNA sequences of seed endophytic bacteria isolated from Lactuca serriola seeds and their closely related type strains. A total of 167 nucleotide sequences were analyzed using MEGA software (Version 7.0, https://www.megasoftware.net) ${ }^{30}$. The evolutionary distances were computed using the Kimura 2-parameter method and trees were constructed using the neighbor-joining method. The optimal tree with the sum of branch length $=1.11$ is shown. The positions containing gaps and missing data were eliminated. A total of 1,176 positions were included in the final dataset.

Effects of isolates on the drought tolerance of $\boldsymbol{A}$. thaliana. After the discontinuation of water supply for 10 days, the soil water content in the drought treatment decreased to $3-5 \%$. Notably, the effects of bacterial treatments on the soil water content differed between the water treatments, as indicated by the significant bacteria $\times$ water treatment interaction $(\mathrm{F}=2.03, P<0.05)$. Under moist conditions, the soil water content of the bacteria-inoculated treatments was similar to that of the control without inoculation. In contrast, the water content of soil inoculated with $K$. cowanii GG1 was higher than that of the control without bacteria under drought conditions $(\mathrm{t}=3.50$, adjusted $P<0.05)$ (Fig. 5a).

In plants grown under drought conditions, the bacterial treatment affected shoot fresh weight $(\mathrm{F}=2.52$, $P<0.05)$ and MDA content $(\mathrm{F}=2.62, P<0.05)$ (Fig. $5 \mathrm{~b}$, and e). In particular, A. thaliana inoculated with $K$. cowanii GG1 produced heavier shoots $(\mathrm{t}=2.97$, adjusted $P<0.05)$ than the untreated control (Fig. $5 \mathrm{~b})$. Root 


\begin{tabular}{|c|c|c|c|c|c|c|c|}
\hline Isolate & Top-hit strains & PPS & SPP & NF & IAA & ACC & Accession \# \\
\hline YJ1 & Pantoea septica & + & + & + & + & + & KCTC 72292 \\
\hline $\mathrm{YJ} 4$ & Kosakonia cowanii & + & + & + & + & + & KCTC 72293 \\
\hline YJ6 & Erwinia tasmaniensis & + & + & + & + & + & KCTC 72294 \\
\hline YJ10 & Cronobacter dublinensis subsp. lausannensis & + & - & + & + & + & KCTC 72295 \\
\hline YJ33 & Cronobacter dublinensis subspp. & + & + & + & + & + & KCTC 72296 \\
\hline SD1 & Kosakonia cowanii & + & + & + & + & + & KCTC 72297 \\
\hline SD2 & Xanthomonas spp. & + & + & + & - & + & KCTC 72298 \\
\hline SD7 & Cronobacter dublinensis subsp. lausannensis & + & + & + & + & + & KCTC 72299 \\
\hline SD8 & Stenotrophomonas maltophilia & - & + & + & - & + & KCTC 72300 \\
\hline SD10 & Psedomonas spp. & + & + & + & - & + & KCTC 72301 \\
\hline SD13 & Paenibacillus hunanensis & + & - & + & + & + & KCTC 43055 \\
\hline SD16 & Pantoea ananatis & + & + & + & + & + & KCTC 72302 \\
\hline SD25 & Pantoea dispersa & + & + & + & + & + & KCTC 72303 \\
\hline MS1 & Kosakonia cowanii & + & + & + & + & + & KCTC 72304 \\
\hline MS2 & Acidovorax spp. & + & - & + & - & + & KCTC 72291 \\
\hline MS3 & Chryseobacterium camelliae & - & + & + & + & + & KCTC 72320 \\
\hline MS4 & Saccharibacillus sacchari & - & - & - & - & + & KCTC 43058 \\
\hline MS7 & Pantoea spp. & + & + & + & + & + & KCTC 72305 \\
\hline MS12 & Stenotrophomonas spp. & + & - & + & - & + & KCTC 72306 \\
\hline MS13 & Pseudomonas spp. & + & - & + & - & + & KCTC 72307 \\
\hline MS14 & Paenibacillus nicotianae & + & + & + & - & + & KCTC 43057 \\
\hline MS18 & Stenotrophomonas indicatrix & - & - & + & - & + & KCTC 72308 \\
\hline MS19 & Curtobacterium oceanosedimentum & + & - & + & - & + & KCTC 49283 \\
\hline MS20 & Xanthomonas spp. & + & + & + & - & + & KCTC 72309 \\
\hline MS24 & Cronobacter dublinensis subsp. dublinensis & + & + & + & + & + & KCTC 72310 \\
\hline MS26 & Cronobacter dublinensis subsp. lausannensis & + & + & + & + & + & KCTC 72311 \\
\hline MS28 & Rhizobium larrymoorei & + & + & + & + & + & KCTC 72290 \\
\hline GG1 & Kosakonia cowanii & + & + & + & - & + & KCTC 72312 \\
\hline GG2 & Stenotrophomonas spp. & - & - & + & - & + & KCTC 72313 \\
\hline GG3 & Exiguobacterium indicum & + & - & + & - & + & KCTC 43053 \\
\hline GG4 & Bacillus altitudinis & + & + & + & - & + & KCTC 43054 \\
\hline GG10 & Enterococcus spp. & + & + & + & - & + & KCTC 21150 \\
\hline GG11 & Pseudomonas fulva & + & - & + & - & + & KCTC 72314 \\
\hline GG15 & Cellulosimicrobium aquatile & + & + & + & - & + & KCTC 49284 \\
\hline GG17 & Paenibacillus hunanensis & + & - & + & + & + & KCTC 43520 \\
\hline GG19 & Pantoea ananatis & + & + & + & + & + & KCTC 72319 \\
\hline GG20 & Enterobacter hormaechei subsp. steigerwaltii & + & + & - & + & + & KCTC 72316 \\
\hline GG21 & Curtobacterium oceanosedimentum & + & + & + & - & + & KCTC 49285 \\
\hline GG23 & Curtobacterium luteum & + & + & + & - & + & KCTC 49286 \\
\hline GG24 & Pantoea dispersa & + & + & + & - & + & KCTC 72317 \\
\hline GG32 & Stenotrophomonas lactitubi & - & + & + & - & + & KCTC 72318 \\
\hline GG33 & Pseudomonas straminea & + & - & + & - & + & KCTC 72315 \\
\hline
\end{tabular}

Table 1. Results of the PGP traits in 42 representative isolates. Positive and negative results for each trait are indicated by '+' and '-, respectively. PPS, Phosphate solubilization; SPP, Siderophore production; NF, Nitrogen fixation; IAA, Indole acetic acid production; ACC, 1-aminocyclopropane-1-carboxylate deaminase production.

dry weight $(\mathrm{F}=1.56, P=0.14)$ and relative water content $(\mathrm{F}=1.10, P=0.38)$ did not differ between the bacterial treatments under drought condition (Fig. 5c, and d), but MDA contents did ( $F=2.62, P=0.01$ ) (Fig. 5e). The soil water content under drought conditions was positively correlated with the shoot fresh weight and negatively with the MDA concentration (Fig. 6a, b, and c). EPS production in media with water potential of $-0.73 \mathrm{MPa}$ was not correlated with soil water content (Fig. 6d), plant shoot fresh weight, or MDA concentration. 


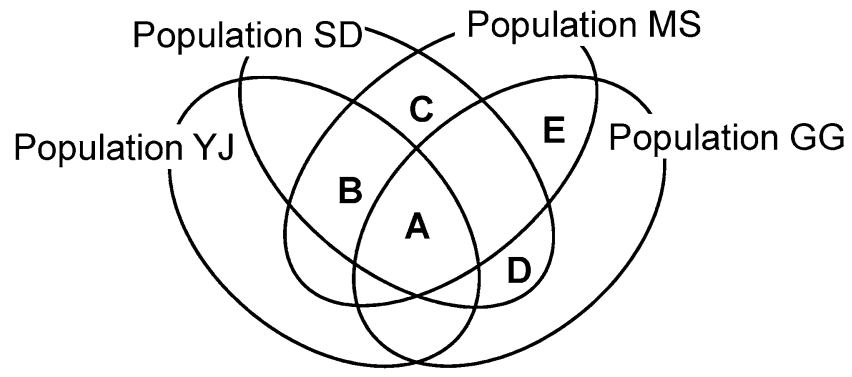
A: Kosakonia cowanii
B: Cronobacter dublinensis
C: Xanthomonas spp.
D: Pantoea dispersa, $\mathrm{Pa}$. ananatis, Paenibacillus hunanensis

\section{E: Curtobacterium oceanosedimentum}

Figure 3. Venn diagram of the shared isolates among the plant populations.

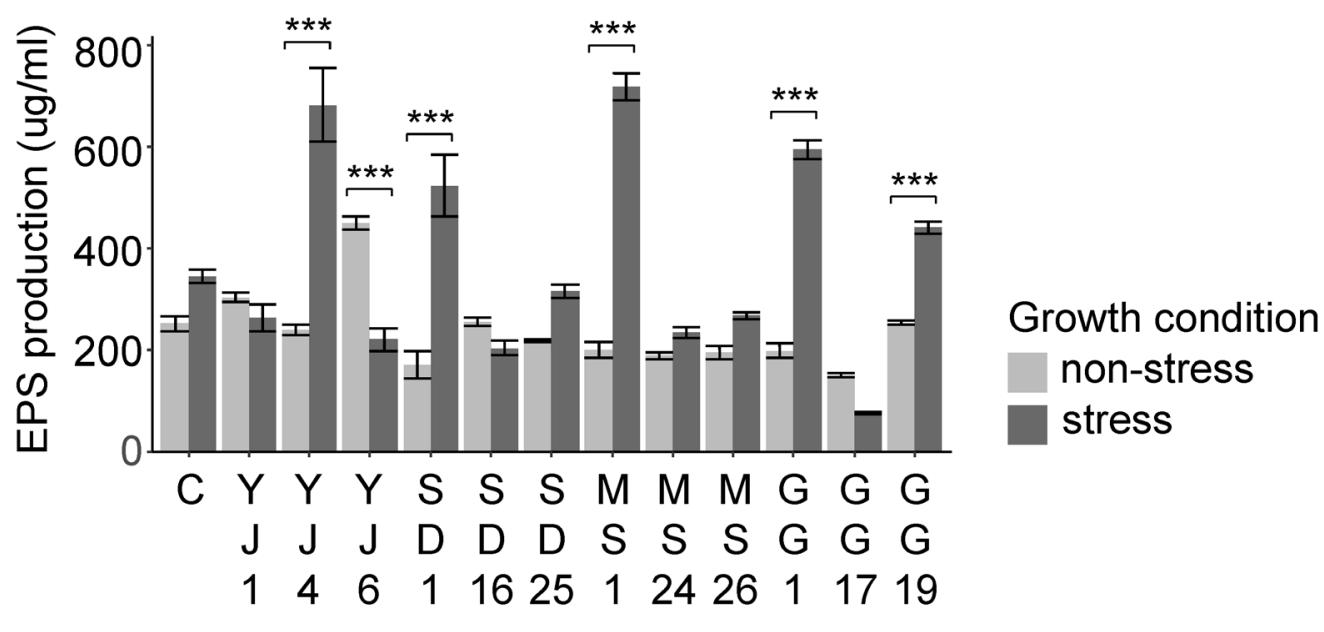

\section{Bacterial isolates}

Figure 4. Exopolysaccharides (EPS) production (mean $\pm \mathrm{SE}$ ) of isolates under non-stress and stress conditions, measured in $\mu \mathrm{g} / \mathrm{mL}$. C, Escherichia coli DH5a.

\section{Discussion}

Invasive L. serriola plants possess diverse seed endophytic bacteria that produce PGP molecules. Some of them survived and increased EPS production in the growth medium under water stress conditions. When grown under drought conditions, A. thaliana plants inoculated with $K$. cowanii GG1 presented a higher shoot biomass than those without bacterial inoculation.

A total of 129 bacterial strains were isolated from L. serriola seeds and were assigned to 42 species. All isolated species, except Ce. aquatile and Cr. dublinensis, have previously been reported as plant-associated bacteria in the rhizosphere, roots, leaves, stems, flowers, or seeds of crop plant species (see Supplementary Table S2 for references). Notably, some of these species have been shown to produce PGP molecules and promote plant growth or stress tolerance. For instance, $\mathrm{Pa}$. ananatis increases the root weight of pepper seedlings ${ }^{31}$, and $\mathrm{Pa}$. dispersa ameliorates salt tolerance in wheat ${ }^{32,33}$. Ba. altitudinis and En. hormaechei subsp. steigerwaltii increase root length in wheat and maize ${ }^{34-36}$. All 42 representative strains in this study exhibited at least one of the tested PGP traits (Table 1), indicating that the invasive plant L. serriola harbors diverse endophytic bacteria with the potential to promote plant growth.

All bacterial isolates produced ACC deaminase. Under environmental stress, the ethylene level increases in plants, resulting in the inhibition of plant growth ${ }^{37}$. ACC is the immediate precursor of ethylene. ACC deaminase cleaves ACC into a-ketobutyrate and ammonia. Thus, bacteria producing ACC deaminase can block ethylene production, which facilitates plant growth under diverse environmental stresses, including drought, salt stress, 


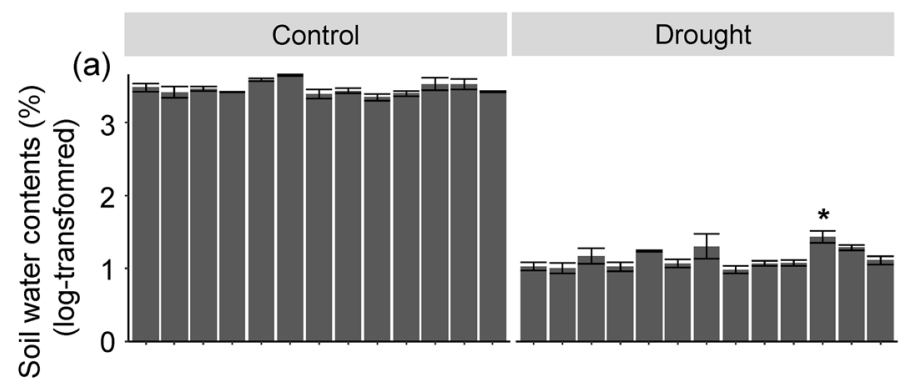

(b)

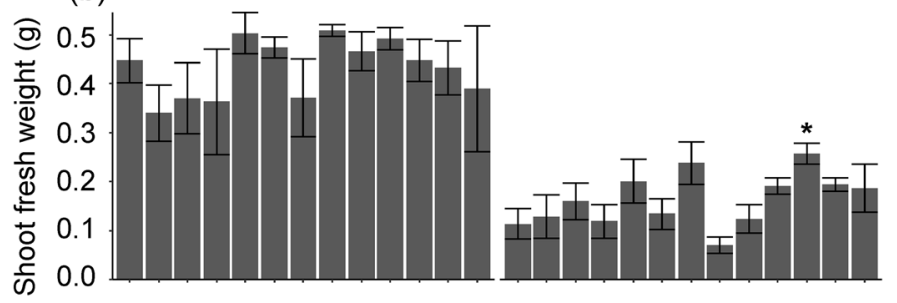

(c)
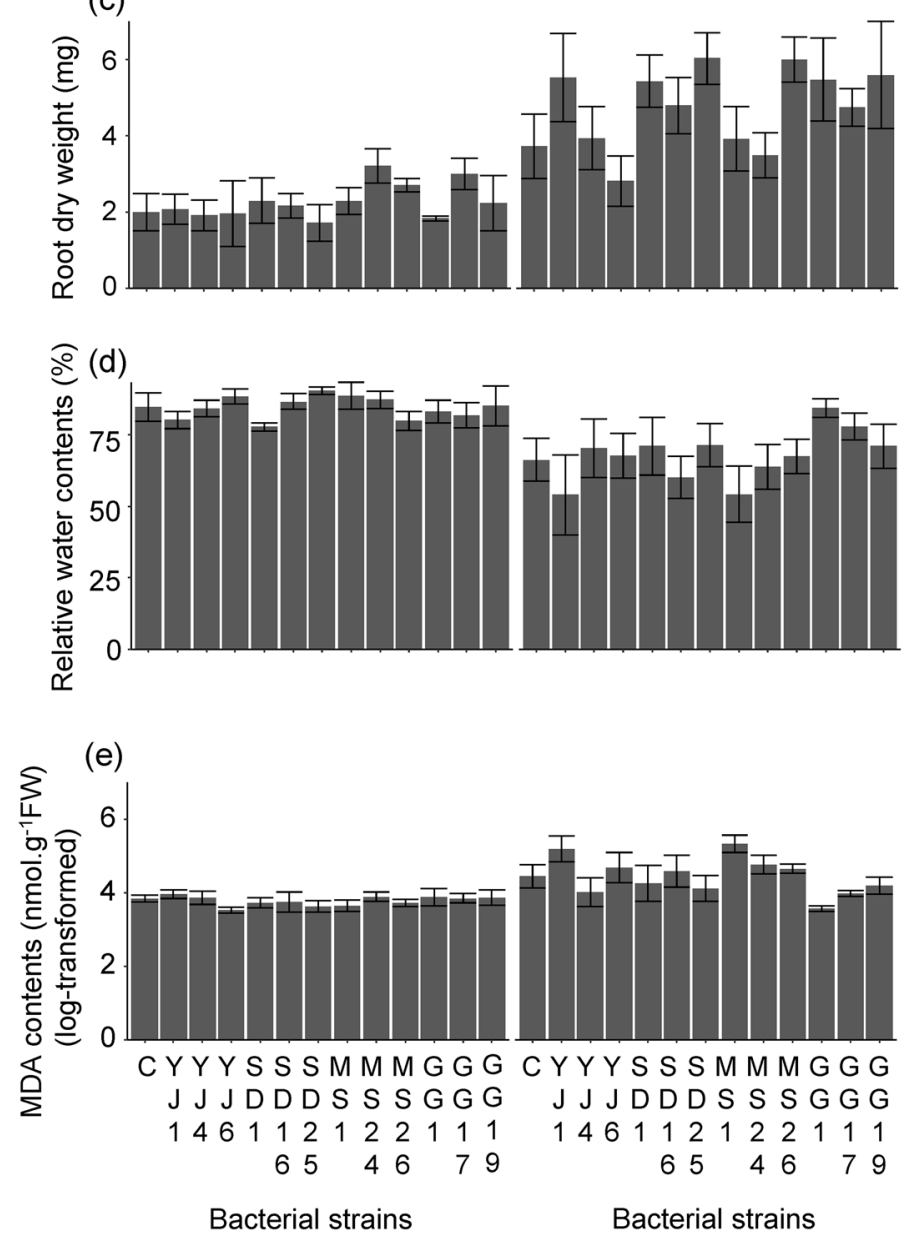

Figure 5. Effects of seed endophytic bacteria on A. thaliana growth and soil water content under drought conditions. (a) Soil water contents. (b) Shoot fresh weight. (c) Root dry weight. (d) Relative water content. (e) Malondialdehyde (MDA) content. Data are presented as mean \pm SE. Results of multiple comparisons with Dunnett adjustment are indicated above each bar. ${ }^{\star} P<0.05$. C: negative control.

and flooding ${ }^{4,38}$. The ACC deaminase activity of seed endophytic bacteria might contribute to the stress tolerance of $L$. serriola. 
(a)

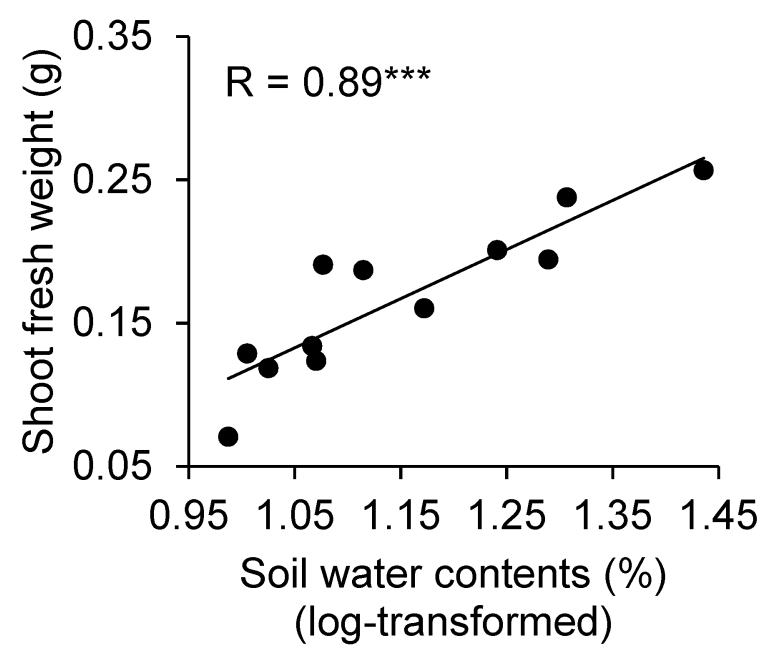

(c)

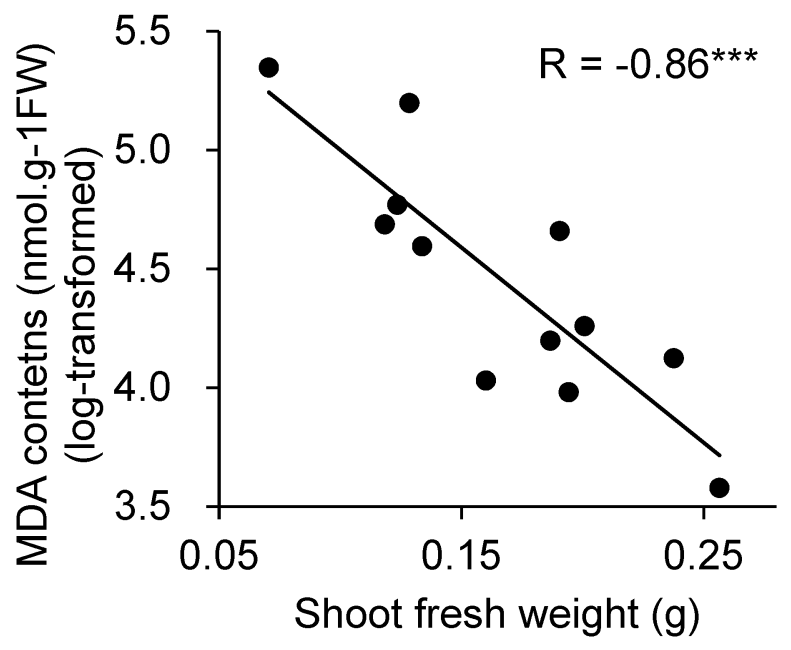

(b)

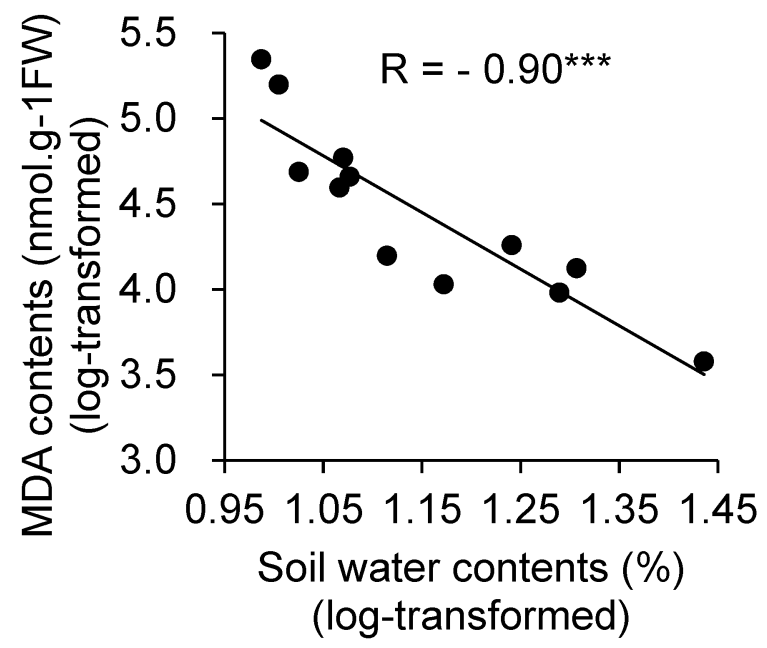

(d)

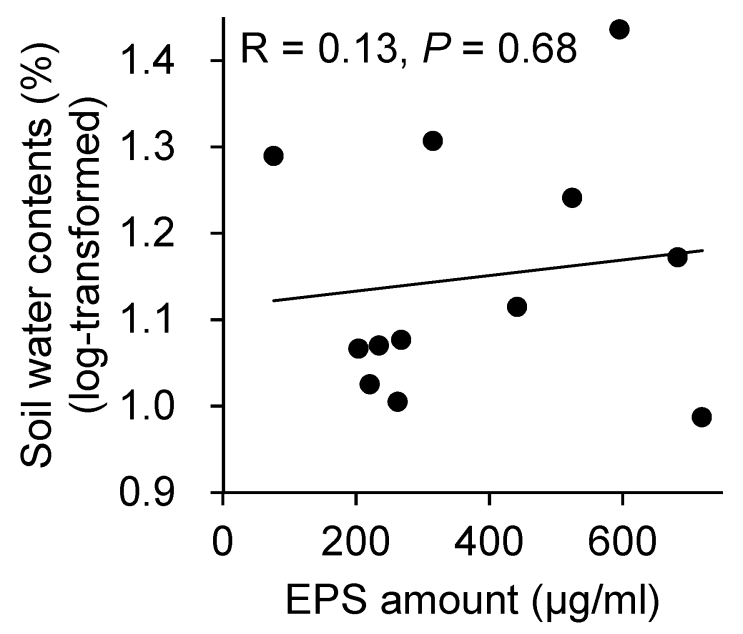

Figure 6. Pearson's correlation coefficients between the soil water content, shoot fresh weight, malondialdehyde (MDA) concentration, and exopolysaccharides production of isolates.

Proteobacteria, particularly Gammaproteobacteria, was the dominant phylum of isolated endophytes, consistent with the root and leaf microbial communities of a congeneric plant species, Lactuca sativa ${ }^{39,40}$. One species of the Gammaproteobacteria, K. cowanii, was detected in all L. serriola populations. K. cowanii (Enterobacter cowanii) was first isolated from the leaf tissues of Eucalyptus plants exhibiting signs of blight disease. Although it is known to cause bacterial spots in Mabea fistulifera ${ }^{41}$, endophytic K. cowanii isolated from Tylosema esculentum exhibited diverse PGP traits ${ }^{42}$. In addition, EPS production by K. cowanii was examined for its application as a plant growth promoter ${ }^{43,44}$.

K. cowanii isolated in the present study produced more EPS when grown in media with a negative water potential than in control conditions. This is a characteristic of bacterial strains that facilitate plant tolerance to environmental stress ${ }^{28,29}$. K. cowanii are known to produce $\alpha$-type heteropolysaccharides, and the polysaccharide composition depends on growth conditions ${ }^{43,44}$. As observed for Pseudomonas aeruginosa, environmental stresses, including drought, can induce the accumulation of diguanylate cyclase, which increases EPS production, although these mechanisms in K. cowanii are unknown ${ }^{45}$.

We hypothesized that $L$. serriola seeds might contain bacterial strains that potentially contribute to the drought tolerance of the species. Although bacterial strains isolated from the rhizosphere, roots, and leaves have been shown to promote plant performance under drought stress ${ }^{46-49}$, it is not known if seed endophytic bacteria also have similar activities. In this study, a bacterium isolated from the seeds, $K$. cowanii GG1, improved the aboveground biomass in $A$. thaliana under drought stress conditions, when compared with untreated $A$. thaliana.

The mutualistic relationship between alien plants and microorganisms has been suggested to facilitate or hinder invasive success ${ }^{13-15}$. The development of a novel beneficial association between the pre-existing microorganisms in the introduced habitats and an alien plant promotes the establishment of the alien species. In contrast, invasive success would diminish if no mutualistic microorganisms are available in the introduced habitats. In 
this context, differential soil microbiota between the native and introduced communities would act as a barrier to the invading alien plant species.

Soil microbiota in the introduced habitats have been postulated as a major source of mutualistic microorganisms, but our results suggest that seed endophytic bacteria might be another source. Microorganisms within seeds of alien plants can disperse with the plant germplasm to novel habitats, and at least some of them, like $K$. cowanii in this study, might be able to promote the plant performance ${ }^{18-20}$. Seed endophytic bacteria, similar to the soil microbiota, might influence the invasive dynamics of alien plants. For instance, if seeds and their beneficial endophytes dispersed simultaneously from their native to the introduced range, seed endophytic bacteria might facilitate the initial establishment of alien plants, a critical step of plant invasion ${ }^{12}$.

Inoculation with K. cowanii GG1 increased soil water content under drought conditions as well as the aboveground biomass of $A$. thaliana. Moreover, the soil water content in the bacteria-inoculated treatments was positively correlated with the aboveground biomass and negatively with the MDA content of plants under drought conditions (Fig. 6). These results indicate that isolated bacteria influence soil water retention under drought stress, consequently affecting the production of shoot biomass and controlling physiological damage to the host plants, as indicated by the MDA concentration ${ }^{46,50}$.

As bacterial EPS production likely improves soil water retention ${ }^{26}$, we expected that bacterial EPS production in the media would be positively correlated with the water content of soil with bacterial inoculation. K. cowanii GG1 produced a relatively high concentration of EPS when grown in media with a negative water potential, and increased the soil water content under drought conditions when it was used to inoculate the seeds and soil. However, no correlation was detected between the EPS production in the media and soil water content of the tested bacterial strains (Fig. 6). In particular, EPS production by K. cowanii MS1 was higher than that of K. cowanii GG1; however, the water content of soil inoculated with $K$. cowanii MS1 was lower than that of the control. The EPS production of $P$. hunanensis GG17 was lower than that of $K$. cowanii GG1, whereas the water content of the soil inoculated with these two strains was similar.

Considering the diverse factors that affect bacterial EPS production, the absence of a correlation between bacterial EPS production in the liquid medium and the water content of bacteria-inoculated soil under drought conditions is not surprising. For instance, the amount and composition of EPS are highly dependent on the growth conditions ${ }^{43,44}$. The different conditions of the liquid media used for EPS quantification and the soil used for plant growth likely caused this discrepancy. In addition, bacterial growth in the rhizosphere is known to depend on the host species, likely influenced by the differential chemical compositions of root exudates ${ }^{51,52}$. As we applied the bacteria isolated from $L$. serriola to A. thaliana, the effects of these plants on the bacterial growth in the rhizosphere might be different. Lastly, $K$. cowanii strains from plant populations might be distinctive genotypes that might affect plant performance differentially.

A caveat of this study is that we used $A$. thaliana instead of host plant $L$. serriola although model plant species have often been used in similar studies ${ }^{49,50,53}$ and $K$. cowanii GG1 was able to colonize the root of A. thaliana (Supplementary Fig. S3). Assessing physiological changes of L. serriola in response to the endophyte treatment would be the next step for more complete understanding of invasive host plant-seed endophyte interactions. Transcriptome analysis of $L$. serriola plants and endophytic bacteria will be a useful approach for the physiological study. Metagenome study would provide information on the genetic mechanisms of the effects of endophytic bacteria on plant performances.

In conclusion, L. serriola, a xerophytic invasive plant species, possesses diverse seed endophytic bacteria. Notably, one isolate, $K$. cowanii GG1, increased EPS production in media with a highly negative water potential, increased soil water content, and promoted the growth of $A$. thaliana under drought conditions. These results imply that invasive plants can disperse along with their symbiotic bacteria, which may promote successful establishment in the introduced area.

\section{Methods}

Seed sources and endophyte isolation. We collected wild L. serriola seeds from four natural populations in the vicinity of the Gwangju Institute of Sciences and Technology, Gwangju, South Korea (Fig. 1, supplementary table S1). Permission to collect $L$. serriola was given by the Ministry of Environment, Korea. Experimental research on plants including the collection of plant material complied with relevant institutional and national guidelines and legislation. Seeds from 4-12 plants from each population were composited, and 80 seeds from each composite sample were used to isolate endophytic bacteria. To sterilize the seed surface, we removed the seed pappi and soaked the seeds in 70\% ethanol for $1 \mathrm{~min}$ and $3 \%$ sodium hydrochloride for $3 \mathrm{~min}$. The seeds were washed three times with sterile distilled water. To confirm surface sterilization, $100 \mu \mathrm{L}$ of the rinsing water was spread on R2A (\#218,263, Difco) and Luria-Bertani (LB) agar (\#7279, Acumedia) and incubated at $25^{\circ} \mathrm{C}$ for 7 days.

The surface-sterilized seeds were pulverized using an autoclaved mortar and pestle, and $1 \mathrm{~mL}$ of sterile distilled water was added to form a mixture in the clean bench (Hanbaek Co. Ltd, Bucheon, Korea). The mixture $(100 \mu \mathrm{L})$ was spread on five different solid media, including R2A (\#218,263, Difco), potato dextrose agar (PDA; \#213,400, Difco), King's B agar (KB; \#60,786, Sigma-Aldrich), LB agar (\#7279, Acumedia), and commercial agar. After incubating the plates at $25{ }^{\circ} \mathrm{C}$ for 1 month, 129 morphologically different colonies were selected. The colonies were subcultured twice and preserved in $20 \%$ glycerol stock solutions at $-80{ }^{\circ} \mathrm{C}$ until further analysis.

To extract bacterial genomic DNA, a single colony was inoculated into the LB broth and incubated in a shaking incubator at $25^{\circ} \mathrm{C}$ and $180 \mathrm{rpm}$. DNA was extracted using the Exgene Cell SV kit (GeneAll, Seoul, South Korea) following the manufacturer's instructions. The $16 \mathrm{~S}$ rDNA gene was amplified by polymerase chain reaction (PCR) using the universal primers 27F (GAGTTTGATCMTGGCTCAG) and 1492R (TACGGYTACCTT GTTACGACTT), as previously described ${ }^{54}$. Amplification was for 35 cycles in T100 Thermal Cycler (Bio-Rad 
Laboratories, CA, USA) using the following program: initial denaturation, $95^{\circ} \mathrm{C}$ for $3 \mathrm{~min}$; denaturation, $95^{\circ} \mathrm{C}$ for $30 \mathrm{~s}$; annealing, $55^{\circ} \mathrm{C}$ for $30 \mathrm{~s}$; elongation, $72{ }^{\circ} \mathrm{C}$ for $1 \mathrm{~min}$; and additional extension for $5 \mathrm{~min}$ at $72{ }^{\circ} \mathrm{C}$. The PCR products were purified using the QIAquick PCR Purification Kit (Qiagen, Venlo, the Netherlands). Sequencing was performed using the Sanger method with universal 16S rDNA 27F and 1492R primer (Macrogen Inc; Seoul, Korea). If required, additional 16S rDNA primers 518F (CCAGCAGCCGCGGTAATACG) and 800R (TACCAG GGTATCTAATCC) were used for sequencing. The nucleotide sequences were aligned using MEGA 7.0 software ${ }^{30}$ and compared with previously reported sequences of bacterial type strains using EZBioCloud (Chunlab, Seoul, South Korea). A phylogenetic tree was constructed using the sequences isolated in the present study and those of the type strains with the highest sequence similarity, using MEGA 7.0. The distance matrix was calculated using Kimura's two-parameter method, and the phylogenetic tree was constructed using the neighbor-joining method $^{55,56}$. The $16 \mathrm{~S}$ rDNA sequences of the isolates have been deposited in the NCBI GenBank, and their accession numbers are provided in Table 1.

Bacterial phenotyping. Of the 129 identified bacterial isolates, 42 representative isolates were selected and their in vitro PGP traits were examined (Supplementary Fig. S1). A representative isolate was randomly selected from a pool of isolated strains in the same phylogenetic clade (Fig. 2). When isolated strains from different plant populations grouped into the same clade, one representative isolate for each population was selected. To examine their ability to solubilize inorganic phosphate, all isolates were inoculated on the National Botanical Research Institute phosphate growth medium (NBRIP) medium $\left[10 \mathrm{~g} / \mathrm{L}\right.$ glucose, $5 \mathrm{~g} / \mathrm{L} \mathrm{Ca}\left(\mathrm{PO}_{4}\right)_{2}, 5 \mathrm{~g} / \mathrm{L} \mathrm{MgCl}{ }_{2} \cdot 6 \mathrm{H}_{2} \mathrm{O}$, $0.25 \mathrm{~g} / \mathrm{L} \mathrm{MgSO}_{4} \cdot 7 \mathrm{H}_{2} \mathrm{O}, 0.2 \mathrm{~g} / \mathrm{L} \mathrm{KCl}$, and $0.1 \mathrm{~g} / \mathrm{L}\left(\mathrm{NH}_{4}\right)_{2} \mathrm{SO}_{4} ; 15 \mathrm{~g} / \mathrm{L}$ agar; $\left.\mathrm{pH} 7.0\right]$ and incubated at $25^{\circ} \mathrm{C}$ for 10 days ${ }^{57}$. A clear halo around the colony indicated that the isolate could solubilize inorganic phosphate. To test siderophore production, we prepared $90-\mathrm{mm}$ test plates containing LB and Chrome Azurol S (CAS) media [60.5 mg/L CAS, $72.9 \mathrm{mg} / \mathrm{L}$ hexadecyltrimethylammonium bromide (HDTMA), $30.24 \mathrm{~g} / \mathrm{L}$ Pipes, $10 \mathrm{~mL} / \mathrm{L}$ iron (III) solution $\left(1 \mathrm{mM} \mathrm{FeCl}_{3} \cdot 6 \mathrm{H}_{2} \mathrm{O}, 10 \mathrm{mM} \mathrm{HCl}\right)$, and 1:3 (v/v) $0.9 \%$ agarose solution] in 1:1 ratio ${ }^{58}$. Each isolate was inoculated at the edge of the LB medium in each test plate and incubated at $25^{\circ} \mathrm{C}$ for 1 week. A color change of the CAS medium from blue to orange indicated siderophore production. Indole acetic acid (IAA) production was determined following Johnston-Monje and Raizada ${ }^{53}$. Each isolate was inoculated on LB medium with $1 \mathrm{~g} / \mathrm{L}$ of L-tryptophan and incubated at $25{ }^{\circ} \mathrm{C}$ for 3 days. A nitrocellulose membrane (Merck Millipore, Darmstadt, Germany) was placed over the agar surface and incubated at $4{ }^{\circ} \mathrm{C}$ overnight. Salkowski reagent $(0.01 \mathrm{M}$ ferric chloride in 35\% perchloric acid; Sigma-Aldrich) was added to the nitrocellulose membrane for $30 \mathrm{~min}$. A pink color indicated IAA production. Nitrogen fixation and 1-aminocyclopropane-1-carboxylate (ACC) deaminase production were tested by culturing each isolate on $\mathrm{DF}$ salt agar medium without a nitrogen source $(4 \mathrm{~g} / \mathrm{L}$ $\mathrm{KH}_{2} \mathrm{PO}_{4}, 6 \mathrm{~g} / \mathrm{L} \mathrm{Na}_{2} \mathrm{HPO}_{4}, 0.2 \mathrm{~g} / \mathrm{L} \mathrm{MgSO}_{4} .7 \mathrm{H}_{2} \mathrm{O}, 1.0 \mathrm{mg} / \mathrm{L} \mathrm{FeSO}_{4} .7 \mathrm{H}_{2} \mathrm{O}, 1.0 \mathrm{mg} / \mathrm{L} \mathrm{H}_{3} \mathrm{BO}_{3}, 10 \mu \mathrm{g} / \mathrm{L} \mathrm{MnSO}$, $70 \mu \mathrm{g} / \mathrm{L} \mathrm{ZnSO}_{4}, 50 \mu \mathrm{g} / \mathrm{L} \mathrm{CuSO}_{4}, 10 \mu \mathrm{g} / \mathrm{L} \mathrm{MoO}_{3}$, and $15 \mathrm{~g} / \mathrm{L}$ agar), without or with $2 \mathrm{mM}$ ACC, respectively. Bacterial growth after incubation at $25^{\circ} \mathrm{C}$ for 5 days indicated nitrogen fixation or ACC deaminase activity ${ }^{59}$.

Screening for drought-tolerant bacteria. Before examining the drought tolerance of the isolated bacteria, we tested if the isolates produced capsular material outside the cells as a quick screening procedure of drought-tolerant bacteria ${ }^{60}$. All isolates cultured on the KB medium were stained using a negative capsule staining method with $10 \%$ nigrosine and $1 \%$ crystal violet ${ }^{61}$. We observed clear halo zones around all isolated bacterial cells, indicating capsular material production (Supplementary Fig. S1).

To examine the drought tolerance of the 42 selected isolates, we measured their growth in trypticase soya broth (TSB; \#211,825, Difco) with a water potential of - $0.73 \mathrm{MPa}$ following Sandhya et al. ${ }^{28,62}$. The water potentials were adjusted with $25 \%$ polyethylene glycol 6000 (\#817,007, Merck), as described by Michel and Kaufmann ${ }^{63}$. After incubating the bacterial isolates in TSB overnight, $1 \%$ volume aliquots of the incubated cultures were transferred to TSB with $-0.73 \mathrm{MPa}$ and incubated in a shaking incubator at $28{ }^{\circ} \mathrm{C}$ and $180 \mathrm{rpm}$ for $24 \mathrm{~h}$. The growth of each bacterial isolate was estimated by measuring the optical density of the sample at $600 \mathrm{~nm}\left(\mathrm{OD}_{600}\right)$ using BioSpectrometer basic (Eppendorf, Hamburg, Germany). The Escherichia coli DH5a strain was used as a control to confirm the experimental protocol of the drought tolerance test and the EPS quantification because this strain is known to produce colonic acid, a kind of EPS ${ }^{64}$. The $\mathrm{OD}_{600}$ of triplicate samples was measured for each isolate.

Quantification of EPS in drought-tolerant bacteria. Of the seed endophytes isolated from each plant population, we selected the two isolates with the highest $\mathrm{OD}_{600}$ values at $-0.73 \mathrm{MPa}$ and one isolate (Kosakonia cowanii) detected in all four plant populations for EPS quantification. A total of 12 bacterial isolates were incubated under non-stress (TSB) and stress (TSB at $-0.73 \mathrm{MPa}$ ) conditions and EPS production was measured following Liu et al..$^{65}$. After culturing the isolates at $28^{\circ} \mathrm{C}$ with shaking at $180 \mathrm{rpm}$ for 3 days, the bacterial cells were harvested by centrifugation at 9,000 rpm for $15 \mathrm{~min}$. The bacterial pellet was dissolved in sterilized deionized water for the measurement of dry bacterial biomass. Three volumes of cold ethanol were added to the separated supernatant and the samples were incubated at $4{ }^{\circ} \mathrm{C}$ overnight to facilitate EPS precipitation. After centrifugation at $15,000 \mathrm{rpm}$ for $30 \mathrm{~min}$ at $4{ }^{\circ} \mathrm{C}$, the precipitated EPS were washed twice with cold absolute ethanol and dissolved in heated deionized water. The concentration of the completely dissolved EPS was measured by the phenol-sulfuric acid method, using D-glucose as a standard ${ }^{66}$.

Effects of isolates on the growth of $\boldsymbol{A}$. thaliana under the drought condition. To examine the effects of seed endophytic bacteria on plant performance, the model plants, i.e., A. thaliana ecotype Col0 , were inoculated twice with 12 isolates, and their EPS production was quantified. After cold treatment at $4{ }^{\circ} \mathrm{C}$ for 1 week, surface-sterilized $A$. thaliana seeds were immersed in a bacterial suspension in phosphatebuffered saline (PBS; $10^{8} \mathrm{CFU} \mathrm{mL} \mathrm{m}^{-1}$ ) for $30 \mathrm{~min}^{67}$. Seeds submerged in PBS were used as a negative control. The 
infected seeds were sown in pots $(8 \mathrm{~cm} \times 7.5 \mathrm{~cm} \times 6 \mathrm{~cm})$ containing a 3:1 (volume) blend of sterile vermiculite (Green Fire Chemicals, Hongseong, Korea) and sand (Glpark, Seoul, Korea ${ }^{46}$. Three weeks after sowing, a bacterial suspension $\left(3.8 \times 10^{5} \mathrm{CFU}\right.$ g soil $\left.{ }^{-1}\right)$ in Hoagland's solution $\left[1.25 \mathrm{mM} \mathrm{KNO}_{3}, 1.5 \mathrm{mM} \mathrm{Ca}\left(\mathrm{NO}_{3}\right)_{2}, 0.75 \mathrm{mM}\right.$ $\mathrm{MgSO}_{4}, 0.5 \mathrm{mM} \mathrm{KH}_{2} \mathrm{PO}_{4}, 0.05 \mathrm{mM} \mathrm{H}_{3} \mathrm{BO}_{3}, 0.01 \mathrm{mM} \mathrm{MnCl}_{2}, 0.002 \mathrm{mM} \mathrm{ZnSO}_{4}, 0.0015 \mathrm{mM} \mathrm{CuSO}_{4}, 0.075 \mu \mathrm{M}$ $\mathrm{NH}_{4} \mathrm{Mo}_{7} \mathrm{O}_{24}$, and $\left.0.074 \mathrm{mM} \mathrm{Fe}-E D T A\right]$ was applied to each pot near the plant's roots ${ }^{46}$. The same amount of Hoagland's solution without bacteria was used as a negative control.

Ten plants were randomly assigned to each bacterial treatment. The pots were randomly positioned in a growth chamber (Hanbaek, Co. LTD., Kyunggi-do, South Korea) and maintained at $22^{\circ} \mathrm{C}$ under a $16 / 8 \mathrm{~h}$ light/ dark photoperiod throughout the experiment. Sterilized deionized water was applied to each pot once or twice per week, and $20 \mathrm{~mL}$ of Hoagland's solution was applied to each pot once per week during the growth ${ }^{46}$. Half of the plants were subjected to drought conditions 5 weeks after sowing by discontinuing their watering.

After 10 days of drought treatment, the plants were harvested and shoot fresh weight was measured immediately. The roots were dried in a drying oven (Hanbaek Co. LTD., Kyunggi-do, South Korea) at $70{ }^{\circ} \mathrm{C}$ for $72 \mathrm{~h}$ and their dry weight was measured. The leaves were frozen in liquid nitrogen and stored at $-80{ }^{\circ} \mathrm{C}$ to measure their malondialdehyde (MDA) content, following Zhang and Huang ${ }^{68}$. In response to drought stress, MDA accumulates in plant leaves as a byproduct of oxidative damage to membrane lipids. The leaves were homogenized in $0.1 \%$ (w/v) trichloroacetic acid (TCA; T6399, Sigma-Aldrich), and the mixture was reacted with $20 \%$ TCA containing $0.5 \%$ thiobarbituric acid (TBA; T5500, Sigma-Aldrich) by boiling at $95^{\circ} \mathrm{C}$ for $15 \mathrm{~min}$. The absorbance of the resulting mixture was measured at $532 \mathrm{~nm}$ using BioSpectrometer basic (Eppendorf). The relative water content of the plants was determined following the methods of Türkan et al. ${ }^{69}$. Leaf fresh weight was measured immediately after harvesting. Leaf turgid weight was measured after submersion in sterilized deionized water for $24 \mathrm{~h}$ at $4^{\circ} \mathrm{C}$ in a refrigerator, and the dry weight was measured after drying at $70^{\circ} \mathrm{C}$ for $72 \mathrm{~h}$. The gravimetric soil water content at the time of harvest was measured after drying the soil at $105{ }^{\circ} \mathrm{C}$ for $72 \mathrm{~h}$.

Statistical analysis. All statistical analyses were performed using R software 4.0.1 (R Foundation for Statistical Computing, Austria). To compare the EPS production of the isolated bacteria, a two-way analysis of variance (ANOVA) was performed, with bacterial isolates, stress conditions, and their interaction as independent variables and EPS production as the dependent variable. Pair-wise differences between the stress conditions of each isolate were evaluated based on the Bonferroni method. To assess the effect of bacterial isolates on plant performance and soil water content, a two-way ANOVA was used, with the drought treatment, isolates, and their interaction as independent variables, and plant traits and soil water content as the dependent variables. Soil water and MDA content was log-transformed to normalize the data, and outliers for all measured traits were excluded from the dataset. As bacterial effects on soil moisture depend on soil water conditions (see results), the control and drought treatments were further assessed separately using ANOVA. Differences between the effects of the negative control and those of the isolated bacteria were evaluated based on Dunnett's adjustment, under control and drought conditions. To determine the relationship between the EPS production of isolates, soil water content, and plant traits, Pearson's correlation coefficients were calculated.

Received: 5 February 2021; Accepted: 15 June 2021

Published online: 25 June 2021

\section{References}

1. Bulgarelli, D., Schlaeppi, K., Spaepen, S., van Themaat, E. V. L. \& Schulze-Lefert, P. Structure and functions of the bacterial microbiota of plants. Annu. Rev. Plant Biol. 64, 807-838 (2013).

2. Reinhold-Hurek, B. \& Hurek, T. Living inside plants: bacterial endophytes. Curr. Opin. Plant Biol. 14, 435-443 (2011).

3. Naveed, M., Mitter, B., Reichenauer, T. G., Wieczorek, K. \& Sessitsch, A. Increased drought stress resilience of maize through endophytic colonization by Burkholderia phytofirmans PsJN and Enterobacter sp FD17. Environ. Exp. Bot. 97, 30-39 (2014).

4. Santoyo, G., Moreno-Hagelsieb, G., del Carmen Orozco-Mosqueda, M. \& Glick, B. R. Plant growth-promoting bacterial endophytes. Microbiol. Res. 183, 92-99 (2016).

5. Ali, S., Charles, T. C. \& Glick, B. R. Amelioration of high salinity stress damage by plant growth-promoting bacterial endophytes that contain ACC deaminase. Plant Physiol. Biochem. 80, 160-167 (2014).

6. Weyens, N., van der Lelie, D., Taghavi, S. \& Vangronsveld, J. Phytoremediation: plant-endophyte partnerships take the challenge. Curr. Opin. Biotechnol. 20, 248-254 (2009).

7. Vandenkoornhuyse, P., Quaiser, A., Duhamel, M., Le Van, A. \& Dufresne, A. The importance of the microbiome of the plant holobiont. New Phytol. 206, 1196-1206 (2015).

8. Card, S. D. et al. Beneficial endophytic microorganisms of Brassica-A review. Biol. Control 90, 102-112 (2015).

9. Shahzad, R., Khan, A. L., Bilal, S., Asaf, S. \& Lee, I. J. What Is there in seeds? Vertically transmitted endophytic resources for sustainable improvement in plant growth. Front. Plant Sci. 9, 24. https://doi.org/10.3389/fpls.2018.00024 (2018).

10. Truyens, S., Weyens, N., Cuypers, A. \& Vangronsveld, J. Bacterial seed endophytes: genera, vertical transmission and interaction with plants. Environ. Microbiol. Rep. 7, 40-50 (2015).

11. Catford, J. A., Jansson, R. \& Nilsson, C. Reducing redundancy in invasion ecology by integrating hypotheses into a single theoretical framework. Divers. Distrib. 15, 22-40 (2009).

12. van Kleunen, M., Dawson, W. \& Maurel, N. Characteristics of successful alien plants. Mol. Ecol. 24, 1954-1968 (2015).

13. Coats, V. C. \& Rumpho, M. E. The rhizosphere microbiota of plant invaders: an overview of recent advances in the microbiomics of invasive plants. Front. Microbiol. 5, 368. https://doi.org/10.3389/fmicb.2014.00368 (2014).

14. Richardson, D. M., Allsopp, N., D’antonio, C. M., Milton, S. J. \& Rejmánek, M. Plant invasions-the role of mutualisms. Biol. Rev. $75,65-93(2000)$.

15. Pringle, A. et al. Mycorrhizal symbioses and plant invasions. Annu. Rev. Ecol. Evol. Syst. 40, 699-715 (2009).

16. Sun, Z.-K. \& He, W.-M. Evidence for enhanced mutualism hypothesis: Solidago canadensis plants from regular soils perform better. PLoS ONE 5, e15418. https://doi.org/10.1371/journal.pone.0015418 (2010). 
17. Kowalski, K. P. et al. Advancing the science of microbial symbiosis to support invasive species management: a case study on Phragmites in the Great Lakes. Front. Microbiol. 6, 95. https://doi.org/10.3389/fmicb.2015.00095 (2015).

18. Dai, Z. C. et al. Different growth promoting effects of endophytic bacteria on invasive and native clonal plants. Front. Plant Sci. 7 , 706. https://doi.org/10.3389/fpls.2016.00706 (2016).

19. Rout, M. E. et al. Bacterial endophytes enhance competition by invasive plants. Am. J. Bot. 100, 1726-1737 (2013).

20. Soares, M. A. et al. Functional role of bacteria from invasive Phragmites australis in promotion of host growth. Microb. Ecol. 72, 407-417 (2016).

21. Kim, Y.-H., Kil, J.-H., Hwang, S.-M. \& Lee, C.-W. Spreading and distribution of Lactuca scariola, invasive alien plant, by habitat types in Korea. Weed Turfgrass Sci. 2, 138-151 (2013).

22. Moon, S.-I. et al. Isolation and characterization of bio-active materials from prickly lettuce (Lactuca serriola). J. Life Sci. 19, 206-212 (2009).

23. Lebeda, A. et al. Acquisition and ecological characterization of Lactuca serriola L germplasm collected in the Czech Republic, Germany, the Netherlands and United Kingdom. Genet. Resour. Crop Evol. 54, 555-562 (2007).

24. Mallory-Smith, C. A., Thill, D. C. \& Dial, M. J. Identification of sulfonylurea herbicide-resistant prickly lettuce (Lactuca serriola). Weed Technol. 4, 163-168 (1990).

25. Glick, B. R. Plant growth-promoting bacteria: mechanisms and applications. Scientifica 2012, 963401. https://doi.org/10.6064/ 2012/963401 (2012).

26. Costa, O. Y. A., Raaijmakers, J. M. \& Kuramae, E. E. Microbial extracellular polymeric substances: ecological function and impact on soil aggregation. Front. Microbiol. 9, 1636. https://doi.org/10.3389/fmicb.2018.01636 (2018).

27. Alami, Y., Achouak, W., Marol, C. \& Heulin, T. Rhizosphere soil aggregation and plant growth promotion of sunflowers by an exopolysaccharide-producing Rhizobiums strain isolated from sunflower roots. Appl. Environ. Microbiol. 66, 3393-3398 (2000).

28. Sandhya, V., Grover, M., Reddy, G. \& Venkateswarlu, B. Alleviation of drought stress effects in sunflower seedlings by the exopolysaccharides producing Pseudomonas putida strain GAP-P45. Biol. Fertility Soils 46, 17-26 (2009).

29. Vardharajula, S. Exopolysaccharide production by drought tolerant Bacillus spp and effect on soil aggregation under drought stress. J. Microbiol. Biotechnol. Food Sci. 9, 51-57 (2020).

30. Kumar, S., Stecher, G. \& Tamura, K. MEGA7: molecular evolutionary genetics analysis version 70 for bigger datasets. Mol. Biol. Evol. 33, 1870-1874 (2016).

31. Kang, S. H. et al. Two bacterial entophytes eliciting both plant growth promotion and plant defense on pepper (Capsicum annuum L). J. Microbiol. Biotechnol. 17, 96-103 (2007).

32. Panwar, M., Tewari, R. \& Nayyar, H. Native halo-tolerant plant growth promoting rhizobacteria Enterococcus and Pantoea sp. improve seed yield of Mungbean (Vigna radiata L) under soil salinity by reducing sodium uptake and stress injury. Physiol. Mol. Biol. Plants 22, 445-459 (2016).

33. Selvakumar, G. et al. Characterization of a cold-tolerant plant growth-promoting bacterium Pantoea dispersa 1A isolated from a sub-alpine soil in the North Western Indian Himalayas. World J. Microbiol. Biotechnol. 24, 955-960 (2008).

34. Egamberdieva, D. et al. High incidence of plant growth-stimulating bacteria associated with the rhizosphere of wheat grown on salinated soil in Uzbekistan. Environ. Microbiol. 10, 1-9 (2008).

35. Pereira, S., Castro, P. \& Research, P. Diversity and characterization of culturable bacterial endophytes from Zea mays and their potential as plant growth-promoting agents in metal-degraded soils. Environ. Sci. Pollut. Res. 21, 14110-14123 (2014).

36. Sun, Z. et al. IAA producing Bacillus altitudinis alleviates iron stress in Triticum aestivum $\mathrm{L}$ seedling by both bioleaching of iron and up-regulation of genes encoding ferritins. Plant Soil 419, 1-11 (2017).

37. Pierik, R., Tholen, D., Poorter, H., Visser, E. J. W. \& Voesenek, L. A. C. J. The Janus face of ethylene: growth inhibition and stimulation. Trends Plant Sci. 11, 176-183 (2006).

38. Glick, B. R. Bacteria with ACC deaminase can promote plant growth and help to feed the world. Microbiol. Res. 169, 30-39 (2014).

39. Cardinale, M., Grube, M., Erlacher, A., Quehenberger, J. \& Berg, G. Bacterial networks and co-occurrence relationships in the lettuce root microbiota. Environ. Microbiol. 17, 239-252 (2015).

40. Yu, Y.-C., Yum, S.-J., Jeon, D.-Y. \& Jeong, H.-G. Analysis of the microbiota on lettuce (Lactuca sativa L.) cultivated in South Korea to identify foodborne pathogens. J. Microbiol. Biotechnol. 28, 1318-1331 (2018).

41. Brady, C. et al. Isolation of Enterobacter cowanii from Eucalyptus showing symptoms of bacterial blight and dieback in Uruguay. Lett. Appl. Microbiol. 49, 461-465 (2009).

42. Chimwamurombe, P. M., Grönemeyer, J. L. \& Reinhold-Hurek, B. Isolation and characterization of culturable seed-associated bacterial endophytes from gnotobiotically grown Marama bean seedlings. FEMS Microbiol. Ecol. 92, fiw083. https://doi.org/10. 1093/femsec/fiw083 (2016).

43. Gao, H. et al. Production exopolysaccharide from Kosakonia cowanii LT-1 through solid-state fermentation and its application as a plant growth promoter. Int. J. Biol. Macromol. 150, 955-964 (2020).

44. Wang, L. et al. Development of sugarcane resource for efficient fermentation of exopolysaccharide by using a novel strain of Kosakonia cowanii LT-1. Bioresour. Technol. 280, 247-254 (2019).

45. Borlee, B. R. et al. Pseudomonas aeruginosa uses a cyclic-di-GMP-regulated adhesin to reinforce the biofilm extracellular matrix. Mol. Microbiol. 75, 827-842 (2010).

46. Huang, X.-F. et al. Mitsuaria sp. and Burkholderia sp. from Arabidopsis rhizosphere enhance drought tolerance in Arabidopsis thaliana and maize (Zea mays L.). Plant Soil 419, 523-539 (2017).

47. Marulanda, A., Barea, J.-M. \& Azcón, R. Stimulation of plant growth and drought tolerance by native microorganisms (AM fungi and bacteria) from dry environments: mechanisms related to bacterial effectiveness. J. Plant Growth Regul. 28, 115-124 (2009).

48. Niu, X., Song, L., Xiao, Y. \& Ge, W. Drought-tolerant plant growth-promoting rhizobacteria associated with foxtail millet in a semi-arid agroecosystem and their potential in alleviating drought stress. Front. Microbiol. 8, 2580. https://doi.org/10.3389/fmicb. $2017.02580(2018)$

49. Sandhya, V., Ali, S. Z., Grover, M., Reddy, G. \& Venkateswarlu, B. Effect of plant growth promoting Pseudomonas spp. on compatible solutes, antioxidant status and plant growth of maize under drought stress. Plant Growth Regulat. 62, 21-30 (2010).

50. Chen, C. et al. Pantoea alhagi, a novel endophytic bacterium with ability to improve growth and drought tolerance in wheat. Sci. Rep. 7, 41564. https://doi.org/10.1038/srep41564 (2017).

51. Mönchgesang, S. et al. Natural variation of root exudates in Arabidopsis thaliana-linking metabolomic and genomic data. Sci. Rep. 6, 1-11 (2016)

52. Zhang, N. et al. Effects of different plant root exudates and their organic acid components on chemotaxis, biofilm formation and colonization by beneficial rhizosphere-associated bacterial strains. Plant Soil 374, 689-700 (2014).

53. Johnston-Monje, D. \& Raizada, M. N. Conservation and diversity of seed associated endophytes in Zea across boundaries of evolution, ethnography and ecology. PLoS ONE 6, e20396. https://doi.org/10.1371/journal.pone.0020396 (2011).

54. Coombs, J. T. \& Franco, C. M. M. Isolation and identification of Actinobacteria from surface-sterilized wheat roots. Appl. Environ. Microbiol. 69, 5603-5608. https://doi.org/10.1128/aem.69.9.5603-5608.2003 (2003).

55. Kimura, M. A simple method for estimating evolutionary rates of base substitutions through comparative studies of nucleotide sequences. J. Mol. Evol. 16, 111-120 (1980).

56. Saitou, N. \& Nei, M. The neighbor-joining method: a new method for reconstructing phylogenetic trees. Mol. Biol. Evol. 4, 406-425 (1987). 
57. Mehta, S. \& Nautiyal, C. S. An efficient method for qualitative screening of phosphate-solubilizing bacteria. Curr. Microbiol. 43, $51-56(2001)$.

58. Milagres, A. M., Machuca, A. \& Napoleao, D. Detection of siderophore production from several fungi and bacteria by a modification of chrome azurol S (CAS) agar plate assay. J. Microbiol. Methods 37, 1-6 (1999).

59. Dworkin, M. \& Foster, J. Experiments with some microorganisms which utilize ethane and hydrogen. J. Bacteriol. 75, 592-603 (1958).

60. Singh, J. K., Adams, F. G. \& Brown, M. H. Diversity and function of capsular polysaccharide in Acinetobacter baumannii. Front. Microbiol. 9, 3301 (2019).

61. Polak-Berecka, M., Waśko, A., Skrzypek, H. \& Kreft, A. Production of exopolysaccharides by a probiotic strain of Lactobacillus rhamnosus: biosynthesis and purification methods. Acta Aliment. 42, 220-228 (2013).

62. Tschaplinski, T. J. et al. The nature of the progression of drought stress drives differential metabolomic responses in Populus deltoides. Ann. Bot. 124, 617-626 (2019).

63. Michel, B. E. \& Kaufmann, M. R. The osmotic potential of polyethylene glycol 6000. Plant Physiol. 51, 914-916 (1973).

64. Hanna, A., Berg, M., Stout, V. \& Razatos, A. Role of capsular colanic acid in adhesion of uropathogenic Escherichia coli. Appl. Environ. Microbiol. 69, 4474-4481 (2003).

65. Liu, S.-B. et al. Structure and ecological roles of a novel exopolysaccharide from the Arctic sea ice bacterium Pseudoalteromonas sp. strain SM20310. Appl. Environ. Microbiol. 79, 224-230 (2013).

66. Dubois, M., Gilles, K. A., Hamilton, J. K., Rebers, P. \& Smith, F. Colorimetric method for determination of sugars and related substances. Analyt. Chem. 28, 350-356 (1956).

67. Yahaghi, Z., Shirvani, M., Nourbakhsh, F. \& Pueyo, J. J. Uptake and effects of lead and zinc on alfalfa (Medicago sativa L.) seed germination and seedling growth: Role of plant growth promoting bacteria. S. Afr. J. Bot. 124, 573-582 (2019).

68. Zhang, Z. \& Huang, R. Analysis of malondialdehyde, chlorophyll proline, soluble sugar, and glutathione content in Arabidopsis seedling. Bio-Protoc. 3, e817 (2013).

69. Türkan, I., Bor, M., Özdemir, F. \& Koca, H. Differential responses of lipid peroxidation and antioxidants in the leaves of droughttolerant $P$. acutifolius Gray and drought-sensitive P. vulgaris L. subjected to polyethylene glycol mediated water stress. Plant Sci. 168, 223-231 (2005).

\section{Acknowledgements}

The authors thank Dr. Hor-Gil Hur, Dr. Hansoo Park and Dr. Kee Dae Kim for their insightful comments. We also thank the associate editor and anonymous reviewers for valuable comments on the manuscript. This research was supported by the Basic Science Research Program through the National Research Foundation of Korea (NRF) funded by the Ministry of Education (NRF-2019R1F1A1058025) and the Water Management Research Program funded by the Ministry of Land, Infrastructure and Transport of the Korean Government (21AWMP-B114119-06).

\section{Author contributions}

Conceptualization: S.J. and E.K.; Methodology and investigations: S.J, T.K., B.C., and Y.K.; Analysis and writing: S.J.; Resources and supervision: E.K.

\section{Competing interests}

The authors declare no competing interests.

\section{Additional information}

Supplementary Information The online version contains supplementary material available at https://doi.org/ 10.1038/s41598-021-92706-x.

Correspondence and requests for materials should be addressed to E.K.

Reprints and permissions information is available at www.nature.com/reprints.

Publisher's note Springer Nature remains neutral with regard to jurisdictional claims in published maps and institutional affiliations.

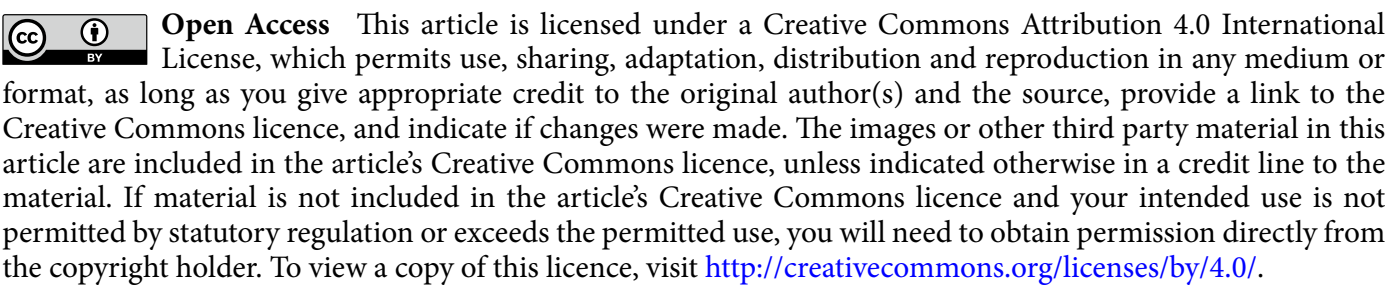

(C) The Author(s) 2021 